\title{
Developing Company Images Through Spiritual Public Relations Facing Covid-19 Outbreak
}

\author{
Aang Kunaifi', Lailatul Qomariyah ${ }^{2}$ \\ Institut Agama Islam Al-Khairat Pamekasan \\ Pamekasan, East Java \\ E-mail: akunaifi@gmail.com
}

\begin{abstract}
,
Public Relations is the company's functional organ in building an image aimed at gaining public trust as a potential market. Through this trust the value of a company has increased, both in aspects of customer loyalty and corporate profits. The ability to increase the value of the company will be the strength to win the competition, so the company is able to maintain sustainability and experience growth. Based on that, a strategy to build and maintain an image is needed. So it is very interesting to examine how the strategy of building a corporate image in the situation of intense business competition and dynamic social change. Therefore, the author tries to conduct studies and research in the field of spiritual public relations. This research was conducted at the Cahaya Berlian Pamekasan Hotel in East Java, with a focus on how the implementation of the public relations strategy at the sharia hotel and what was done by the management in building and maintaining the company's image. The uniqueness as the only sharia hotel at Pamekasan requires management to display spiritual differentiation, this is where the points to be obtained by researchers. Besides other facts, the company's ability to survive in a pandemic condition is an interesting plus point to be investigated. To get comprehensive information, researchers interviewed informants directly from the owner, manager, employees, customers, and the community around the hotel. The results showed that the application of the public relations strategy was done through a human relations approach, and the media relations strategy was implemented according to their respective goals. Human relations approach, aimed at maintaining internal and external relations of the company environment. So that good relations between fellow employees, stake holders, customers, the community and regulators are harmoniously established. As for media relations, it is intended to build and maintain a general corporate image through social media and direct communications. In another aspect, this study also found the importance of the owner's spiritual character. This spiritual character has created public sympathy that is relevant to the general purpose of the company. The above proves that there are three things that must be considered in building the company's image through the spiritual strategy of public relations, namely the value of public relations itself, human relations and media relations, and the third is the personal character of the owner. So that the target of public relations activities to be effective for improving the company's image
\end{abstract}

Keywords: Corporate image, spiritual public relations, human relations, media relations

\section{INTRODUCTION}

Competition in the business world encourages the emergence of new thoughts for the creation of products and services that provide value to consumers. Companies in the field of services, especially hotels, must be smart to meet consumer needs and subsequently to satisfy consumers. Thus, only quality companies can compete and dominate the market from so many needs.

Hotel Cahaya Berlian Syariah Pamekasan is a service business in the accommodation sector. This hotel has quality facilities in it by developing the concept of sharia in its operations. The increasing standard of living of the Pamekasan community in particular, and the Indonesian people in general has resulted in increasing demands from the public for the quality of services and the products or 
services used. Consumer expectation to be served well and get satisfaction is a construction that is influenced by service quality. In this case, quality assurance is a top priority and is used as a benchmark in business competition.

It takes creative thinking in maintaining the existence of a service in the midst of the rise of hospitality centers. Because it maintains a positive image of other hotel competition. The facilities provided by the hotel do not always bring a positive image, therefore good communication between management and customers is needed. One organ function that plays an important role is Public Relations. This corporate organ is needed to run a company program that aims to create a positive image in the community. Public Relations has functions including::

1. Analyzing public opinion and attitudes regarding issues that affect the organization's plans.

2. Providing advice to management relating to decision making to measuring organizational social responsibility.

3. Conduct research, supervise conducting evaluations on a regular basis. These activities include marketing, financial programs, and maintaining various parties' communication.

4. Actively fall in the organization's work program implementation to change public policy.

5. Participate in giving advice regarding staff recruitment and training.

6. Also define and implement policies using communication skills.

In short, public relations is expected to be able to interact and create favorable public opinion for management and customers. Public relations is a professional organ and is an important factor in achieving organizational goals in an appropriate and sustainable way because public relations is the survival of the organization concerned.

Thus, in addition to completing facilities, public relations is also needed to create a positive image in the community. The image is built through fostering good relations between management and customers.

\section{LITERATURE REVIEW Public Relations}

Acording to Frank Jefkins which is contained in book of Syaifuddin S. Gassing states that public relations are a sum that summarizes the overall planned communication, both inside and out, between an organization and its audience in order to achieve specific goals based on mutual understanding.

W. Emerson Reck, PR Director, quoted by Oemi Abdurrahman, defines public relations as follows: "PR is the continuing procces of keying polices, services and actions to the best interest of those individual dan groups whose confidence and good will and individual or institution covest, and secondly, it is the interpretation of these politicies services and action to assure complete understanding and appreciation". Public relations is a continuation of the process of determining the process of determining policies, determining services and attitudes that are tailored to the interests of people or groups so that the institution or trust and goodwill from them. Second, the best implementation of wisdom, service and appreciation. 
While Howard Bonham, vice chairman quoted by Oemi Abdurrahman defines public relations as an art to create a better public understanding, which can deepen public trust in a person or an organization .

Based on the above understanding, it can be explained that public relations is an activity to instill and gain understanding, goodwill, trust, appreciation from the public towards companies, especially the general public, so that public opinion that will benefit the survival of an agency or an institution will arise.

Therefore it is concluded that public relations is an effort in the form of activities or systematic programs to establish good relationships with customers, establish good cooperation, mutual support and benefit for the company with customers and between one company with another company. Public relations must be able to implement capabilities professionally so as to create good communication between companies.

\section{Public Relations Strategy}

According to Cutlip, the Public Relations process refers to the managerial approach. The process of strategic planning in public relations consists of: Fact Finding, Planning, Communication and Evaluation. Kasali adapted it to: collection, facts, problem definition, planning and programs, action and communication and evaluation.

The public relations strategy planning process can be explained as follows:

\section{Fact Finding}

This first step includes investigating and monitoring, finding data and gathering facts before taking action. This step provides the basis for all the steps whether the other problem solving process by determining, what is happening now? In the situation analysis process, it is necessary to have a detailed analysis of internal and external factors in the problem situation to provide practitioners with the information needed to be able to assess their strengths, weaknesses, opportunities and even threats.

\section{Planning}

The information gathered in the first step is used to make decisions about programs, objectives, strategic actions, tactics and communication objectives. The making of plans and programs is to make basic strategic decisions what will be done in what order to respond to or anticipate problems or even opportunities.

\section{Communication}

The third step involves implementing a specific action program for each public to achieve the program's goals. In implementing this program public relations activities must include seven $\mathrm{C}$ public relations communications, namely credibility, continuity and consistency, channels and capacity of audience.

4. Evaluation

The final step in this process involves assessing the preparation, implementation and results of the program. Evaluation is an ongoing and important process carried out. In the final analysis, program evaluation involves a lot of knowledge outside of scientific research techniques. Conduct an evaluation of an activity, whether the objectives have been achieved or not. The evaluation can be 
carried out continuously. The results of this evaluation will be the basis for the next activity.

\section{Definition of Image}

Image is a picture of mind, which is a picture that is in someone's mind. Image is a set of beliefs that is connected with an image that is owned or from experience. The image can also be interpreted as an impression of someone or an individual about something that arises as a result of his knowledge and experience.

From the above understanding, it can be concluded that the company's image is the character of a company that was built to get an impression from the public, both internal and external public. For internal public, the company's image is built to gain a good perception about the company and create employee loyalty. As for the external public, the company's image is built for the purpose that the company can be received positively in the midst of its public.

Company image in the eyes of the public can be seen from the opinions or communal mindset when perceiving the reality that occurs. Thus, one thing that needs to be understood in connection with the process of forming a company's image is the perception (which develops in the public mind) of reality (which appears in the media).

\section{Spiritual}

The spiritual values in question are religious or religious values, in this discussion, of course, the values or rules of Islamic religion that originate from the Qur'an and Sunnah. Conceptually, spiritual values are a code of creation, feeling, heart and intention (implementation) guided by the integrity of the faith, piety, and obedience to the shari'ah of Allah SWT. Spiritual values in PR are expected to be able to move the market's rational appeal which will further increase customer confidence and ultimately increase customer loyalty.

\section{METHODS}

This research is a type of field research with a qualitative approach. The presence of researchers, as absorbers and digestors of information to be reported in the form of scientific papers. Information obtained from primary sources includes company owners, managers, employees, customers, and community leaders. While secondary sources of information were obtained from company social media, company documents and media.

Data is systematically collected according to categories namely; observation data, interview results, and documentation results. The data collected is first tested for its level of validity through the credibility of the information content test, crosschecked by triangulation, its accuracy is measured through transferability. While the informants were tested for validity through dependability and confirmability.

After the content and source of the data are verified, then the data is then presented in a systematic presentation to be discussed using relevant literature review. On the basis of this discussion, the researcher makes an objective conclusion. 


\section{DISCUSSION}

\section{Research Object Profile}

Cahaya Berlian Hotel Pamekasan is the only BoutiqueHotel on Madura Island. With a thematic concept, the hotel has a four-story building that stands firmly on a plateau in the City of Pamekasan, Madura Island, East Java. Although basically this hotel carries the concept of sharia, but it does not rule out the possibility of not accepting non-Muslims as hotel customers, but this hotel is welcome for customers without discriminating religion.

Figure 1. Organizational Structure

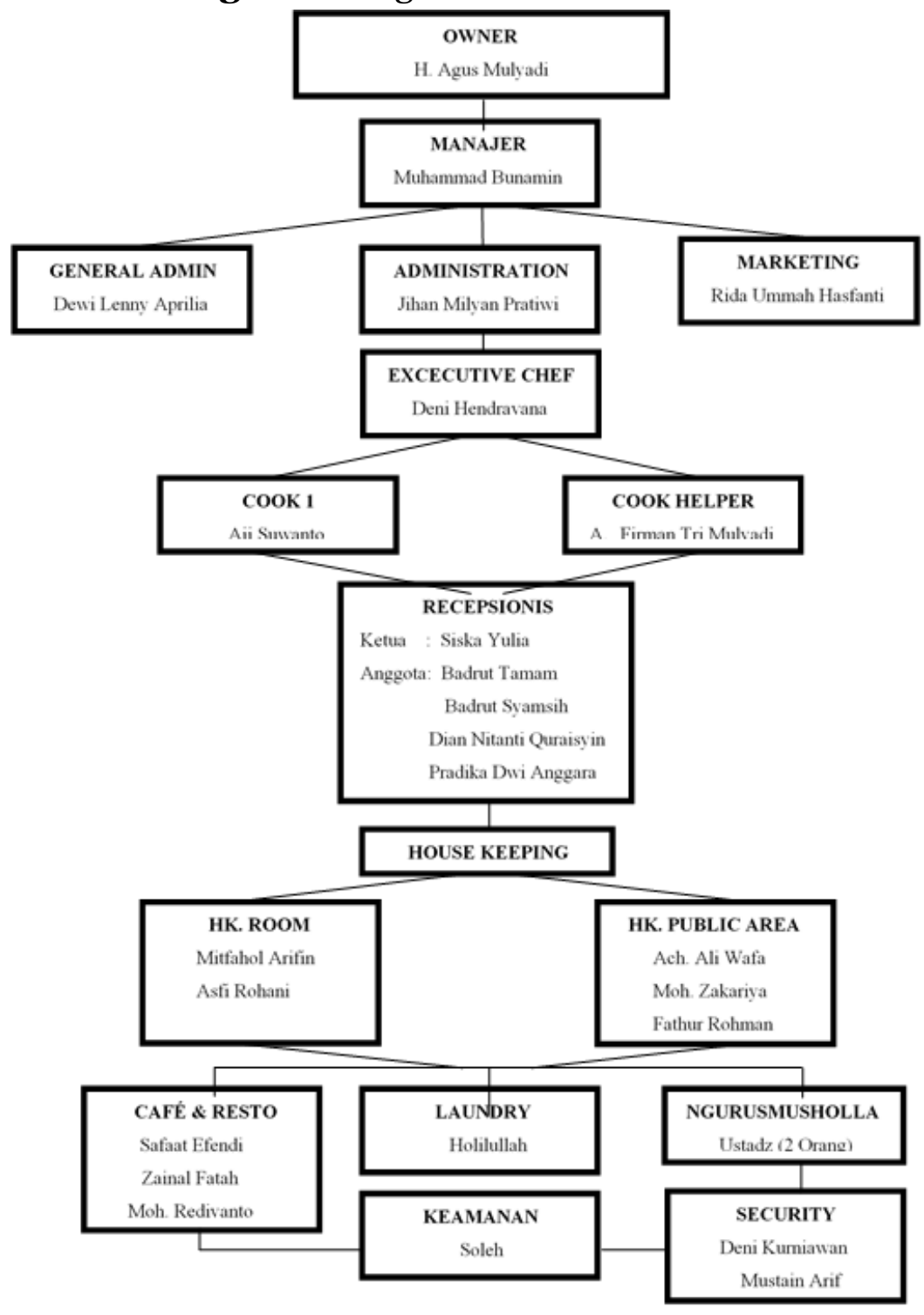

\section{Public Relations Strategies in Maintaining Image}

Strategies that can be carried out in the public relations function include:

a. Human relations

The leader provides information to employees to improve and maintain the company's existence. Therefore, management must continue to pay attention to the needs of its employees (internal public) because employees are assets, especially in the 
service business. Employees are required to maintain their appearance and performance. Instead, company management must provide a comfortable environment so that they are comfortable and loyal.

Examining special relationships between fellow employees informally. Human relations exists to safeguard spiritual elements which include nature, time, behavior, personal and other psychological aspects contained in human beings that lead to happiness and satisfaction. Human relations includes:

- Employee relations

According to Effendy employe relations is a relationship with employees. Public relations whose duties and functions maintain internal and external relations in a company. Public relations is not just sitting in the office, but must communicate directly with employees ranging from employees who work must be neatly dressed and clean in the office room or manual workers or subordinate workers. If all that is done then the work will be smooth and and the trust of them can be maintained and nurtured.

The form can be in the form of attitudes or policies that do not discriminate between employees with other employees, and without discriminating between race and customer Muslim or non-Muslim at the hotel. The next employee relations activities are activities that maintain good relations between employees and superiors through good communication.

- Customer care

To be able to do good attention to customers, it is necessary to add skills or training for employees. Improving the quality of human resources will have an impact on improving the quality of customer care, such as the ability to welcome customers, how to respond to guest complaints, and offer assistance. All of this is done to maintain and maintain good relations with all employees, customers and the public.

- Spiritual event

Namely activities in order to improve religiosity and attitude of spirituality, morals, and obedience that reflect universal goodness.

- Corporate Social Responsibility

All company activities related to community interests. In this case there is no tendency of the company to get material benefits.

\section{Media Relations}

Philip Lessy explained that media relations is a relationship with the media to do publicity or respond to media interests against the interests of the organization. Public relations also carries out publication, information and giving activities based on applicable regulations. Not only good relations with the community and stakeholders, but also a good relationship with the media.

1) Social Media

This media is used to get benefits and maintain a positive image. Communication in the form of product publications, services, and events that are held. 
These publication activities are carried out through social media. Among them the most popular are:

- Instagram

Instagram is a social media that is used by many people, especially for the promotion of products or services. Instagram can load photos and is equipped with a caption of the photos. This social media is used to publish with the aim of maintaining and improving the image. Every time there is an event, active public relations to post it with pictures and videos that have been enhanced.

- Facebook

Facebook is one of the most popular social media by all people. This is an opportunity for public relations to carry out publication activities. If the Instagram only contains photos and captions then Facebook can have more functions, namely users can write anything explicitly, Facebook can also upload photos and captions because if only Instagram, then it will be limited in writing caption, and Facebook chooses more room for this.

- Traveloka

The application for accommodation tickets is also important, one of which is Traveloka. Its access with the aim to introduce the hotel to the public from all facilities and prices, also to make it easier for customers in terms of heating hotel services via online and to find out comments from customers about the hotel, to be used as a guide in evaluating hotels, in improving future hotels. this is the same with pegi-pegi and ticet com..

2) Direct communications

Publication or promotion by visiting educational institutions and also existing institutions such as government offices, offices, and institutions that have the potential to hold events and others.

Figure 2. Public Relations Strategy in Hotel Business

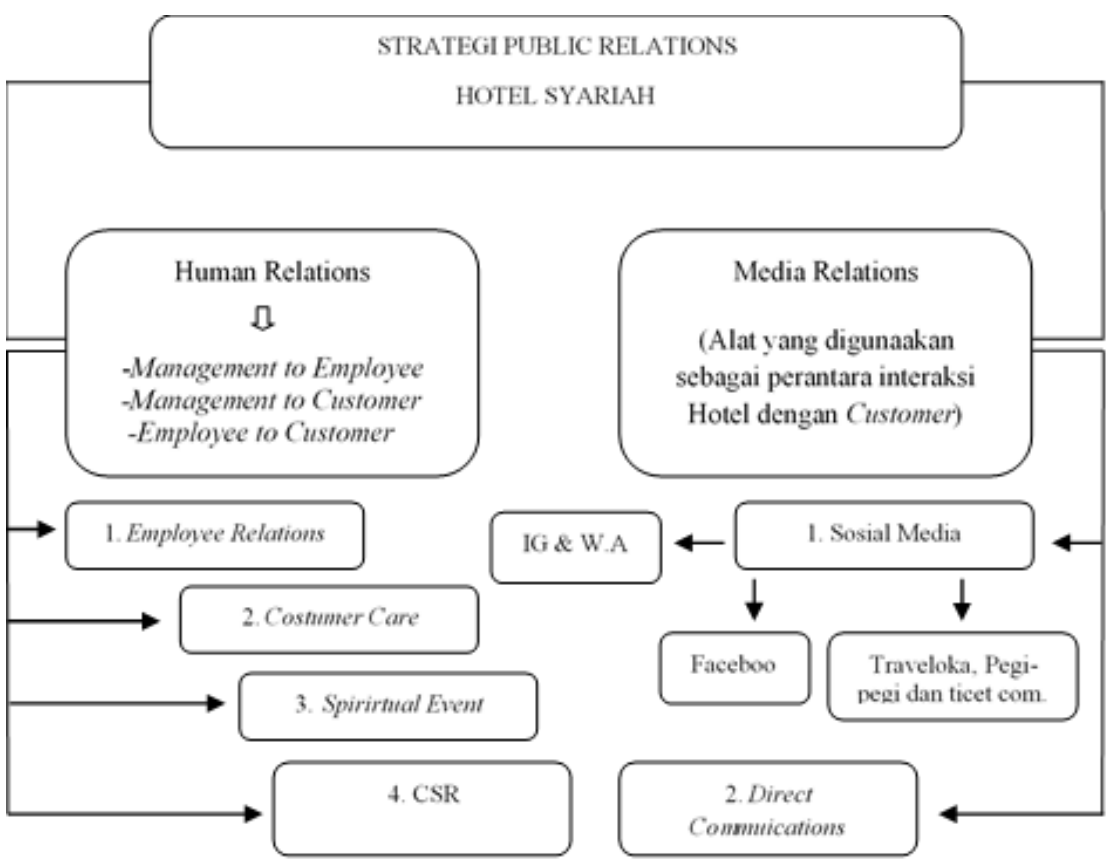




\section{Management Efforts in Defending the Image}

Implementation of the above public relations requires carrying capacity of adequate human resources. Management has made efforts in creating and maintaining the image, as follow:

1. Excellent service

Relations with the public owned by the company, depicted by the quality of service shown by the hotel to its customers or customers, and satisfaction with the services provided by the hotel will be shown by the customer, while still giving their trust in the hotel to continue to provide services to the maximum extent possible to them, among them:

- Reliability, namely serving properly and correctly as when the customer held an event the hotel served him correctly and correctly, meaning that in preparing the customer event in accordance with what was conceptualized by the customer.

- Tangibles or physical ability, meaning in the services provided by the hotel in physical terms, namely by providing complete facilities.

- Responsiveness that is serving quickly, such as when there are complaints from customers and solve problems quickly and accurately.

- Assurance that is, to guarantee the availability of products and services in accordance with the publications submitted.

- Empati, namely in maximizing service to customers, namely in the attitude of care and non-formal assistance that can be provided by each employee.

Fitzsimmons states that there are five indicators of public service namely reliability which is marked by the provision of appropriate and correct services, tangibles which are characterized by adequate provision of both human resources and other resources, responsiveness marked by the desire to serve consumers quickly, assurance marked by ethical levels moral in providing service and the last empathy which is marked by the level of willingness to know the wants and needs of consumers.

\section{Employee Maintenance}

Because the weaknesses and weaknesses and the inability of employees to carry out their duties in providing quality services to consumers in viewing the capabilities and image of the hotel. The impact is also very significant in influencing the company's image, so that the performance of public relations must be extra in implementing imaging strategies to cover weaknesses arising from the maximum ability of human resources owned by employees in carrying out their duties.

For this reason, it is necessary to strengthen human resources (HR) in carrying out good and excellent services in order to prove the quality of services owned by hotels by approaching someone who is an expert in hospitality, in order to deepen the knowledge of human resources in terms of hospitality, and provide intense HR skills training. Increased HR skills will affect creativity and avoid boredom at work. Furthermore, employees will work effectively, provide excellent service, and be able to overcome problems. This is in line with the existing theory that improvements in 
employee work effectiveness can be achieved by increasing employee knowledge, employee skills and employee attitudes towards their duties.

Figure 3. Management Effort Scheme to Maintain Image

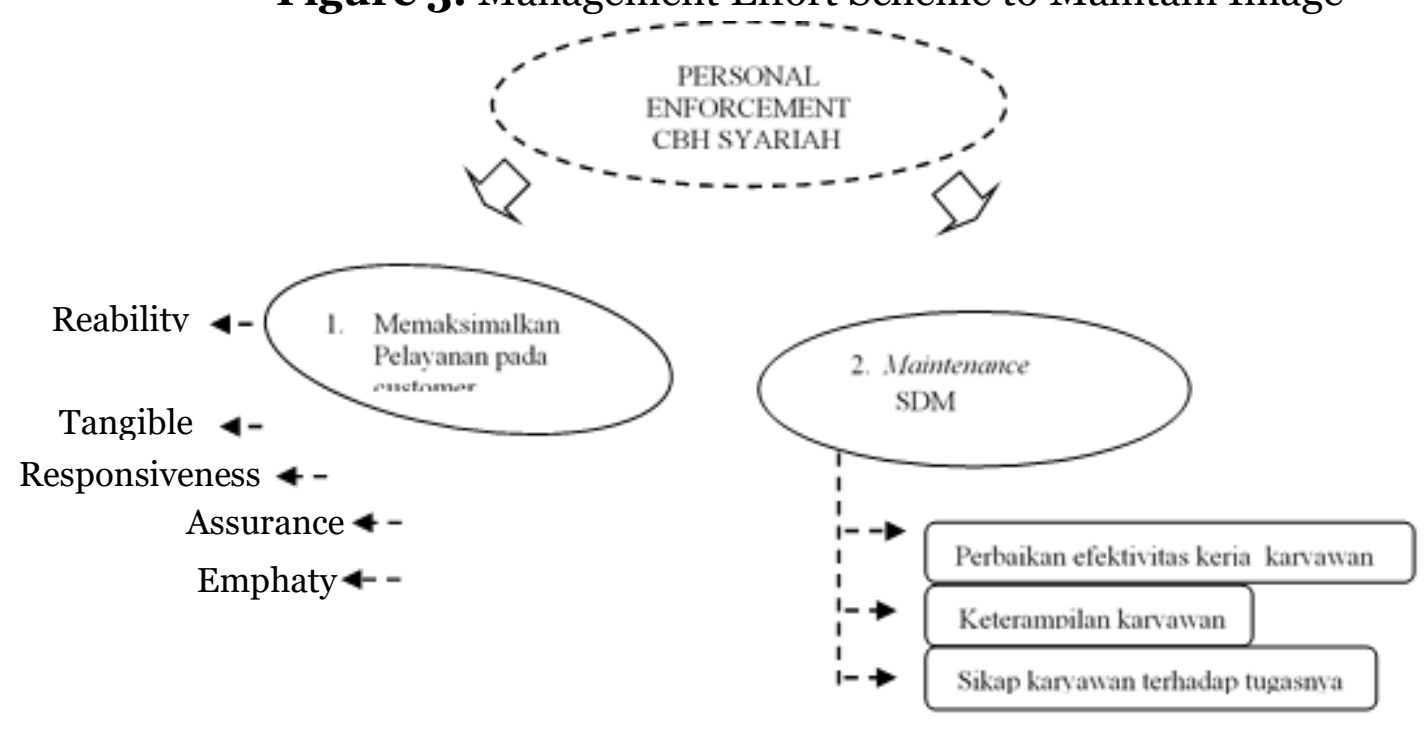

\section{Spiritual Public Relation in Developing an Image Facing the Covid-19 Outbreak}

Spiritual in the public relations function is the injection of spiritual values on all public relations strategies programmed by the company. Spiritual values include sharia law, in the dimension of halal-haram law. The concept of spiritual public relations encompasses three dimensions in organizations namely:

- Owner Leadership

Personal spiritual is the main capital in dealing with outbreaks and other calamities. The personal spirituality of the owner and employees is the power and motivation to remain optimistic in business during covid-19 outbreak. The belief that al-rizqu biyadillah is a foothold to keep thinking positive and seeing a solution. Thus personal energy, especially in the self-owner and management, will be more optimal for thinking creative ideas and self-confidence than the stunted thinking and self-giving attitude.

- Work Culture

Strengthening spiritual values in the spirit of the company's leadership owner will create a work culture that is based on spiritual values. This culture can be created through internalizing sharia knowledge within each employee. This activity must be carried out routinely to have a real impact, for example the emergence of a culture of mutual reminding between employees to always behave and behave in accordance with the shariah principle.

- System

Business organizations or company management functions to create an atmosphere that supports the application of spiritual values in all its activities, especially in public relations. The form of activities in creating such an atmosphere is, by including important matters related to spiritual values in the form of rules or operating standards and procedures. In addition, the 
organization's spiritual activities can take the form of recitation events, social services, and Islamic literacy.

The adoption of this public relations spiritual strategy is relevant to the economic situation and competition during the 19th plague. It is undeniable that the plague that hit during this semester made it easier for people to get closer to Allah. People who are increasingly spiritual will naturally choose products and services that are in line with sharia principles

\section{CONCLUSION}

The implementation of public relations strategy in maintaining the company's image is arranged in two strategies, namely: human relations which includes management to employee, management to customer, and employee to customer. The second strategy is media relations in the form of both direct relations and digital media.

Maximizing excellent service to customers because customer satisfaction will form a good and sustainable image. Maintenance of employees to be able to properly implement public relations programs. The public relations spiritual strategy is relevant to be implemented during the covid-19 Outbreak

\section{REFERENCES}

Abdurrahman, Oemi. (2001). Dasar-Dasar Public Relation. Bandung: Citra Aditya Agung, Sulih. (2005). Strategi Public Relations. Jakarta: PT. Gramedia Pustaka Utama

Buchari, Alma. (2008) Manajemen Pemasaran dan Pemasaran Jasa. Bandung: Alfabeta

Gassing S, Syaifuddin \& Suryanto. (2016). Public Relations. Yogyakata: Penerbit Andi Kunaifi, Aang. (2016). Manajemen Pemasaran Syariah Pendekatan Human Spirit; Konsep, Etika, Strategi, dan Implementasi. Yogyakarta: Maghza Pustaka Manulang. (2008). Manajemen Personalia, Jakarta: Yudistira

Onong, Effendy Uchana. (1993) Human Relations dan Public Relations. Bandung: Mandar Maju

Potlak, Lijan Sinambela. (2011). Manajemen Sumber Daya Manusia, Jakarta: Bumi Aksara

Soemirat, Soleh. (2002). Dasar-Dasar Public Relations, Bandung: Remaja Rosdakarya

Soleh, Ardianto Soemirat \& Elvinaro. (2005). Dasar-Dasar Public Relations. Bandung: PT. Remaja Rosdakarya.

Widjaja, A W.. (1993). Komunikasi dan Hubungan Masyarakat. Jakarta: Bumi Aksara 